\title{
ON THE OCCURRENCE OF SUBFOSSIL PEDIASTRUM ALGAE IN A FLANDRIAN CORE AT KIRKKONUMMI, SOUTHERN FINLAND
}

\author{
Pentti Alhonen and Sinikka Ristiluoma
}

\begin{abstract}
Alhonen, Pentri and Ristiluoma, Sinikka 1973: On the occurrence of subfossil Pediastrum algae in a Flandrian core at Kirkkonummi, southern Finland. Bull. Geol. Soc. Finland 45, 73-77.

Subfossil green algae of Pediastrum were observed in a Flandrian core in south-west Finland. Their greatest relative abundance was slightly above the rational border for Tilia $\left(\mathrm{T}_{\mathrm{o}}\right)$ in the pollen stratigraphy. The authors believe that the species indicate the presence of eutrophic chlorococcal plankton, thus reflecting a more or less productive environment of sedimentation. The proximity of the transgressive Litorina Sea and the contemporaneous moist Atlantic climate are also assumed to have made the physical and chemical conditions in the lake phase of the site favourable for their growth. These observations and the data from the literature show that Pediastrum provides a useful indication of environmental changes, and that its occurrences in sediments is thus deserving of attention.
\end{abstract}

Pentti Albonen and Sinikea Ristiluoma, Department of Geology and Palaeontology, University of Helsinki, 00170 Helsinki 17, Finland.

\section{Introduction}

The purpose of this biostratigraphic study is to discuss the occurrence and significance of subfossil Pediastrum algae (Chlorophyta, Protococcales) in a bog profile in southern Finland. In the literature total counts of Pediastrum have been presented in connexion with pollen diagrams, but only a few attempts have been made to interpret their ecological significance. Green algae of the genus Pediastrum have previously been noted in the Pleistocene sediments of Finland by Salmi (1963) and Lappalainen (1970), and this study may serve as a further contribution on this subject.

\section{Methods}

The methods used were similar to those normally employed in sediment studies. The core was obtained with the Hiller sampler, and dated by pollen analysis. $10 \% \mathrm{KOH}$ was used in the preparations of pollen slides. Siliceous matter was removed by treatment with $\mathrm{HF}$, and 200 tree pollen grains were counted. Pediastrum algae were counted on the pollen slides and identified by comparison with the illustrations in Brunnthaler (1915), Sebestyén (1968) and Whitford and Schumacher (1969).

\section{Description of the site and the profile}

The site is situated in the parish of Kirkkonummi, south Finland $\left(60^{\circ} 12^{\prime} \mathrm{N}\right.$ Lat. $24^{\circ} 32^{\prime}$ E Long). It is a pine bog, which covers 1.5 ha. The altitude of the threshold is about $39 \mathrm{~m}$. The profile is taken from the western part of the bog (Fig. 1). The stratigraphy is as follows: 


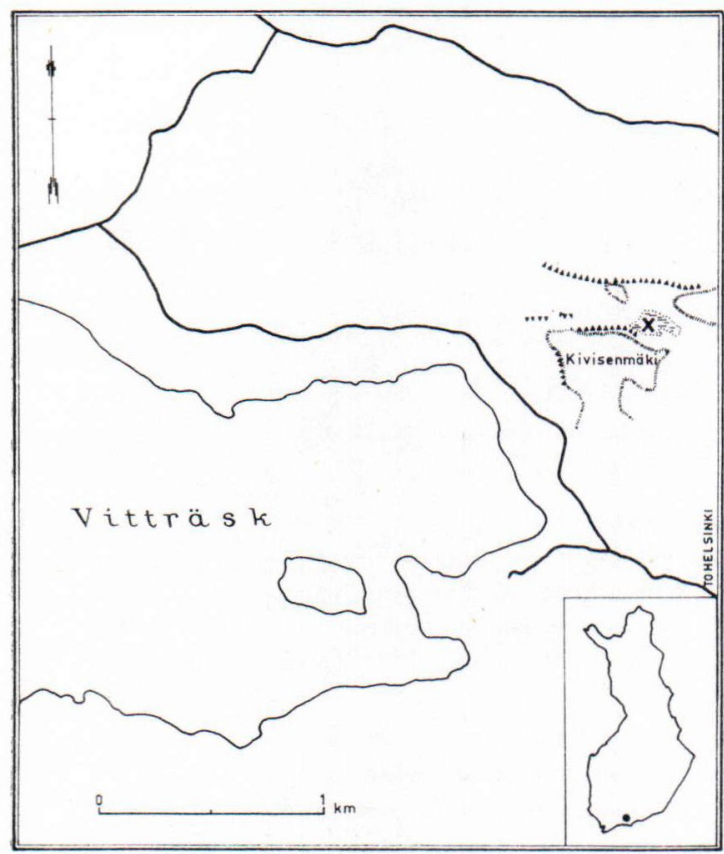

Fig. 1. Map showing the location of the site.

\begin{tabular}{|c|c|c|}
\hline $\begin{array}{l}\text { Depth below } \\
\text { surface } \\
(\mathrm{cm})\end{array}$ & $\begin{array}{c}\text { Layer } \\
\text { No. }\end{array}$ & Description \\
\hline $0-325$ & 6 & $\begin{array}{l}\text { Forest sedge peat including two } \\
\text { ash layers at levels of } 155 \mathrm{~cm} \\
\text { and } 255 \mathrm{~cm} \text {. The uppermost } \\
1 \mathrm{~m} \text { was not analysed because } \\
\text { of the poor humification of } \\
\text { the peat }\end{array}$ \\
\hline $325-380$ & 5 & Sphagnum peat \\
\hline $380-480$ & 4 & $\begin{array}{l}\text { Coarse detritus gyttja with abun- } \\
\text { dant Carex fragments, brown } \\
\text { in colour. The lowermost part } \\
\text { of this layer consists of some } \\
\text { centrimetres of fine detritus } \\
\text { gyttja }\end{array}$ \\
\hline $480-500$ & 3 & $\begin{array}{l}\text { Clay-gyttja, which according to } \\
\text { subfossil diatoms represents } \\
\text { the isolation sediment from } \\
\text { the Ancylus Lake stage of the } \\
\text { Baltic Sea }\end{array}$ \\
\hline $500-545$ & 2 & $\begin{array}{l}\text { Silty clay containing diatoms } \\
\text { typical of the Ancylus Lake }\end{array}$ \\
\hline $545-$ & 1 & $\begin{array}{l}\text { Sand and fine sand. This layer } \\
\text { continues downwards }\end{array}$ \\
\hline
\end{tabular}

Pollen stratigraphy and the dating of the profile

The pollen diagram (Fig. 2) is zoned according to the principles used by Donner (1963; see also 1971). In addition to the Flandrian zone boundaries, the rational limit of Tilia $\left(\mathrm{T}_{\mathrm{o}}\right)$ is used as the local pollen zone boundary VI/VII in dating the sediments of this site (see Alhonen 1967, p. 11). The upper part of zone $\mathrm{V}$ is visible in the sand and silty clay. The zone boundary $\mathrm{V} / \mathrm{VI}$ lies in the clay-gyttja. $\mathrm{T}_{\mathrm{o}}$ is in the coarse detritus gyttja, and pollen zone boundary VIII/ IX occurs in the forest sedge peat.

The numerous radiocarbon datings from profiles in south-west Finland recently summarized and discussed by Donner (1971, Table 1, p. 285; see also Fig. 2) show that the zone boundary $\mathrm{V} / \mathrm{VI}$ can be dated at c. 8000 B. P. and the zone boundary VIII/IX at c. 2500 B. P. (Donner 1971, p. 284). The age of $T_{o}$ in this profile cannot be given with certainty, because C-14 dates for the rational limit of Tilia differ greatly in southern Finland. If some generalizations can be made, the $\mathrm{T}_{\mathrm{o}}$ limit can be dated at c. 7500 B. P. on the south coast of Finland (Aartolahti 1967, Fig. 6).

\section{The occurrence of Pediastrum in the profile and its interpretation}

Fig. 3 shows the stratigraphical distribution of Pediastrum in the profile. From the first column of the diagram it is evident that the main occurrence of these algae coincides with the coarse detritus gyttja, just above the rational border for Tilia $\left(\mathrm{T}_{\mathrm{o}}\right)$. There are some findings of Pediastrum in the minerogenous sediments of pollen zone $\mathrm{V}$, too.

Four kinds of Pediastrum were identified: Pediastrum duplex Meyen, P. araneosum (Racib.) G. M. Smith, $P$. araneosum var. rugulosum (G. S. West) G. M. Smith and $P$. boryanum (Turp.) Menghini. As is seen from Fig. 3, $P$. duplex is the predominant species in the succession. It 


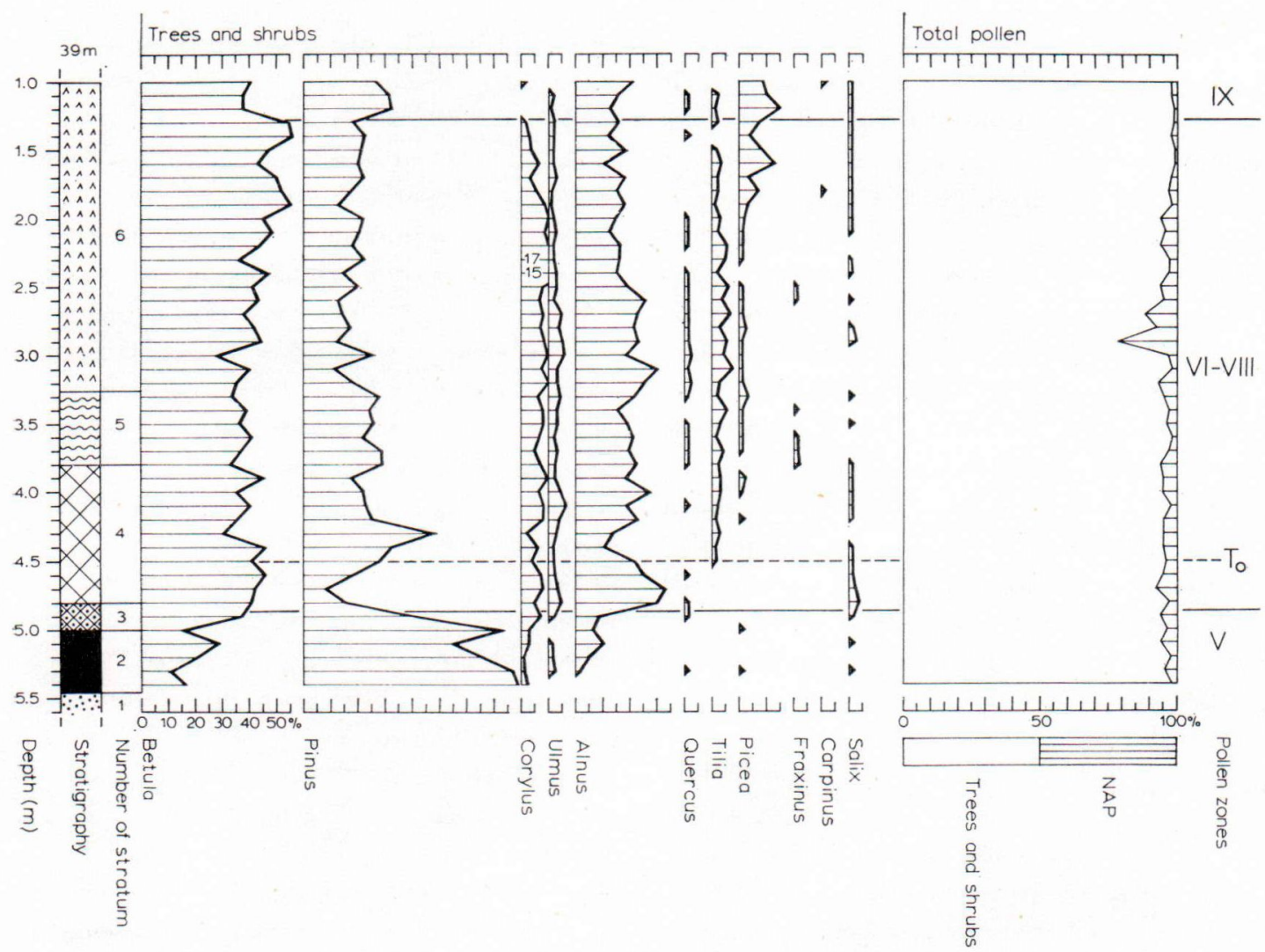

Fig. 2. Pollen diagram of the site.
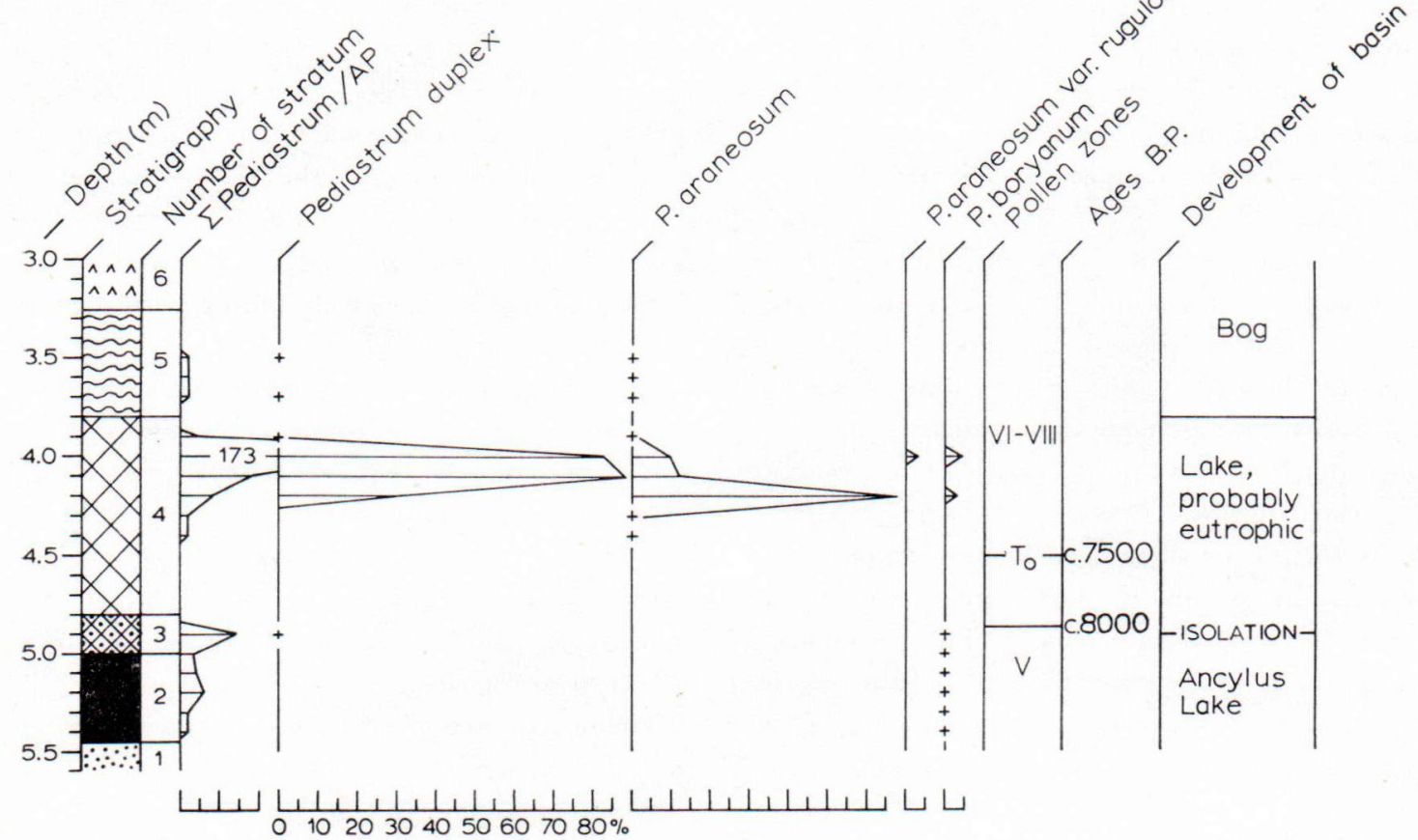

Fig. 3. The stratigraphical distribution of Pediastrum in the profile and its correlation to the pollen stratigraphy and the geological development of the site. The presence of Pediastrum is indicated by + . 
has a frequency of $88 \%$ at a depth of $410 \mathrm{~cm}$ in the profile. Pediastrum araneosum was found throughout the analysed levels, showing its greatest relative abundance $(68 \%)$ at a level of $420 \mathrm{~cm}$. The occurrence of $P$. araneosum var. rugulosum and $P$. boryanum is only sporadic.

The occurrence of these species may be assumed to indicate the presence of eutrophic chlorococcal plankton, the most usual dominant of which appears to be Pediastrum (see Hutchinson 1967 , p. 388). Thus it seems likely that the most abundant occurrence of Pediastrum may here reflect a more less productive environment of sedimentation. The increase in the relative frequency of these algae may also be considered to be related to a rising water level, which interpretation is supported by the observations of e.g., Jørgensen (1954).

\section{Discussion}

When the occurrence of Pediastrum algae is examined from the palaeocological point of view, it may be noted that the site lies close to the coast of the Litorina Sea, the altitude of which (L I) is about $35 \mathrm{~m}$ in this area (Ristiluoma, unpublished), and accordingly it did not reach the site, since the altitude of the threshold of the bog is about $39 \mathrm{~m}$. In view of the pollenanalytical dating of the main occurrence of Pediastrum in the stratigraphy, it may, however, be presumed that the proximity of the transgressive Litorina Sea and the moist Atlantic climate prevailing at that time made the physical and chemical conditions in the lake phase of the site favourable for these algae. Thus Pediastrum algae may have general significance as indicators of water level changes caused by the climate (cf. Nilsson 1964, Fig. 5).

As Pediastrum algae have been found in various sedimentary series, we will now briefly discuss their ecological significance in the light of some examples given in the literature. Salmi (1963) investigated Pediastrum in the sediments of two sites, Sompiojärvi and Kalkkarovuoma, in Fin- nish Lapland. He identified seven species, viz. $P$. boryanum, $P$. duplex, $P$. integrum, $P$. kawraiskyi, $P$. muticum, $P$. simplex and $P$. tetras (Salmi, op. cit., p. 113). Their occurrence in the stratigraphy of these sites is probably causally connected with the climatic conditions and the calcareous sedimentation environment (Kalkkarovuoma).

Lappalainen (1970) also found abundant $P_{e}$ diastrum algae in his studies of peat deposits in central Finnish Lapland. Pediastrum boryanum, $P$. integrum and $P$. kawraiskyi were typical species and were concentrated mainly in the transition between »lateglacial» and "postglacial» (see Lappalainen 1970, p. 54).

As the representatives of the genus Pediastrum are mostly planktonic, Sebestyén $(1968,1969)$ attempted to relate the chydoric Cladocera/ Pediastrum $(\mathrm{C} / \mathrm{P})$ ratio with fluctuations in the water level during the development of Lake Balaton, Hungary. Pediastrum simplex var. clathratum, which is characteristic of large lakes, dominated the pelagic phases of the lake.

Goulden (1970) identified three distinct forms of Pediastrum, viz. P. boryanum, $P$. duplex and $P$. simplex, in the bottom deposits of Lago di Monterosi, Italy. The abundance of $P$. boryanum during the early history of the lake may be related to the colder climate which probably occurred then. Pediastrum duplex and $P$. simplex were commoner during the warmer and relatively eutrophic conditions of the recent history of Lago di Monterosi (see Goulden 1970, Fig. VIII-3 A, p. 104; also pp. 107-111).

Livingstone et al. (1958) found a number of Pediastrum boryanum colonies in the sediments of four Alaskan lakes (Fig. 9), showing an increase from the lower to the upper strata. The greatest abundance of $P$. boryanum was found in the shallowest lakes, and is probably the result of the special conditions obtaining there. It has been suggested (Livingstone et al. 1958, p. 207) that the progressive increase of $P$. boryanum may reflect shoaling as the lake filled in.

The occurrence of Pediastrum in lake sediments of the South-western United States shows that 
the frequency of this algal genus is highest in sediments referred to the pluvial period. Whiteside (1965) found four species of Pediastrum in a core from Potato Lake, Coconino County, Arizona, viz. $P$. boryanum, $P$. araneosum, $P$. sculptatum and $P$. integrum. He suggested that oligotrophic conditions existed in Potato Lake during the pluvial, and that eutrophication began in post-pluvial times (Whiteside 1965, Fig. 1). Pediastrum boryanum was the predominant species during the pluvial period, while $P$. araneosum and $P$. sculptatum show their greatest relative abundance during the eutrophic phase of the history of the lake.

From our own observations and the cases quoted above, it is apparent that Pediastrum algae indicate environment changes. Their occurrence in sediments thus deserves attention, since they may profitably be used as palaeoecological and palaeolimnological tools.

\section{REFERENCES}

Aartolahti, Torve (1967) Zur rationellen Tilia-Pollengrenze (To) in Finland. Fennia 97 (1), 30 pp.

Alhonen, Pentti (1967) Palaeolimnological investigations of three inland lakes in south-western Finland. Acta Bot. Fennica 76, 59 pp.

Brunnthaler, Jos. (1915) Chlorophyceae 2. In: A. Pascher: Die Süsswasserflora Deutschlands, Österreichs und der Schweitz. Heft 5, 250 pp.

Donner, J. J. (1963) The zoning of the Post-glacial pollen diagrams in Finland and the main changes in the forest composition. Acta Bot. Fennica 65, 40 pp.

Donner, J. J. (1971) Towards a stratigraphical division of the Finnish Quaternary. Comment. Phys.-Math. 41: $281-305$.

Goulden, Clyde E. (1970) The fossil flora and fauna (other than siliceous fossils, pollen and chironomid head capsules). In: G. Evelyn Hutchinson: Ianula: an account of the history and development of the Lago di Monterosi, Latium, Italy. Transactions of the American Philosophical Society. New Series 60 (4): $102-111$.

Hutchinson, G. Evelyn (1967) A Treatise on Limnology II. Introduction to Lake Biology and the Limnoplankton. John Wiley \& Sons, Inc., New York 1967, $1115 \mathrm{pp}$.

JørGENSEN, S. (1954) A pollen analytical dating of Maglemose finds from the bog Aamosen, Zealand. Geol. Survey Denmark 80: 159-187.
Lappalainen, Eino (1970) Über die spätquartäre Entwicklung der Flussufermoore Mittel-Lapplands. Bull. Comm. géol. Finlande 244, 79 pp.

Livingstone, D. A., Bryan, Jr., Kirk and Leahy, R. G. (1958) Effects of an artic environment on the origin and development of freshwater lakes. Limnol. Oceanogr. 3: $192-214$.

Nrusson, TAGE (1964) Entwicklungsgeschichtliche Studien im Ageröds Mosse, Schonen. Lunds Universitets Årsskrift. N. F. Avd. 2. Bd 59 (8), 34 pp.

Salmi, Mart'ti (1963) On the subfossil Pediastrum algae and molluscs in the Late-Quaternary sediments of Finnish Lapland. Arch. Soc. »Vanamo» 18 (2): 105 -120 .

Sebestyén, Olga (1968) Remains of Pediastrum Kawraiskyi Schmidle (Chlorophyta, Protococcales) in the sediments of Lake Balaton. Annal. Biol. Tihany 35: $203-226$.

Sebestyén, Olga (1969) Studies on Pediastrum and Cladoceran remains in the sediments of Lake Balaton, with reference to lake history. Mitt. Internat. Verein. Limnol. 17: 292-300.

Whiteside, Melbourne C. (1965) On the occurrence of Pediastrum in lake sediments. Journal of the Arizona Academy of Science 3 (3): 144-146.

Whitford, L. A. and Schumacher, G. J. (1969) A manual of the fresh-water algae in North Carolina. Tech. Bul. No. 188. Published by The North Carolina Agricultural Experiment Station, 313 pp.

Manuscript received, September 5, 1972. 